\title{
WHOLE HATCHERY WASTE MEAL AS ALTERNATIVE PROTEIN AND CALCIUM SOURCES IN BROILER DIETS
}

\author{
HARINA INTEGRAL DE RESIDUOS DE INCUBADORA, COMO FUENTE ALTERNATIVA \\ DE PROTEÍNA Y CALCIO EN LA DIETA DE BROILERS
}

\author{
Abiola, S.S. ${ }^{1 *}$, Radebe, N.E. ${ }^{2}$, Westhuizen, C. v. d. ${ }^{1}$ and Umesiobi, D.O. ${ }^{1}$ \\ ${ }^{1}$ School of Agriculture and Environmental Sciences. Central University of Technology. Bloemfontein. \\ South Africa. *abiolass@yahoo.com \\ ${ }^{2}$ Glen College of Agriculture. Glen. South Africa.
}

\section{AdDitional KeYWORDS}

Fish meal. Broiler carcass. Feed costs.

\section{SUMMARY}

A study was conducted in which processed whole hatchery waste meal (WHWM) replaced fish meal (FM), protein for protein, in broiler diets at $0,10,20$ and $30 \%$ levels. There were 45 birds per treatment and 15 birds per replicate. The feeding trial which lasted for 42 days, was carried out at the Poultry Unit, Agricultural Research Council, Glen. Chemical analysis of the two test ingredients indicated that WHWM had higher contents of ash $(18.12 \%)$ and ether extract $(23.94 \%)$. However, crude protein content of $\mathrm{FM}$ was $73.18 \%$ while that of WHWM was $42.26 \%$. Calcium-phosphorus ratio was 16.6:1 for WHWM as against 1.5:1 in the FM. Broilers fed with diet 2 had highest values for feed intake $(118.25 \mathrm{~g} / \mathrm{bird} /$ day $)$ and weight gain $(50.16 \mathrm{~g} / \mathrm{bird} / \mathrm{day})$ while those fed with diet 3 were superior in efficiency of feed utilization (2.31). Results obtained for carcass traits decreased with increase in the levels of WHWM in the diets. Broilers fed with control diet had highest mean values for eviscerated weight $(2.20 \mathrm{~kg})$ and dressing percentage $(77.86 \%)$. Values recorded for abdominal fat and internal organs (liver, lungs, heart and gizzard) did not show any particular trend. Similarly there were slight variations in the results obtained for blood parameters. Cost of feed intake/bird decreased with increase in the levels of WHWM in the diets.

It can be concluded from the results of this study that $10 \%$ of FM can be replaced with WHWM in broiler diets without adverse effects on growth and carcass traits. This approach of turning waste

Recibido: 26-7-10. Aceptado: 7-11-11.

\author{
Palabras claVe adicionales \\ Harina de pescado. Dietas de broilers. Costes.
}

into a valuable product will provide alternative protein and calcium sources in broiler diets and solve the problem of hatching waste disposal in the hatchery industry.

\section{RESUMEN}

Se realizó un estudio en el que se sustituyó la proteína de harina de pescado (FM) por la proteína de residuos integrales de incubadora (WHWN) profesados en dietas de pollos a niveles del 0,10, 20 y $30 \%$. Se utilizaron 45 aves por tratamiento y 15 por repetición. El ensayo de alimentación que duró 42 días fue llevado a cabo en la Unidad de Avicultura del Agricultural Research Council, Glen. Los ánalisis químicos de los ingredientes utilizados indicaron que el WHWM contenía mayor cantidad de ceniza $(18,12 \%)$ y de extracto étereo $(23,94 \%)$. Sin embargo el contenido de proteína bruta de FM fue de $73,18 \%$ mientras que el de WHWM fue de $42,26 \%$. La relación calcio fósforo fue 16,6:1 y la de FM 1,5:1. Los pollos alimentados con la dieta 2 consumieron mayor cantidad de alimento $(118,25 \mathrm{~g} /$ ave/día) y ganaron más peso (50,16 g/ave/día) mientras que los alimentados con la dieta 3 tuvieron mejor transformación de alimento (2,31). Los resultados obtenidos para las características de la canal fueron peores a medida que se aumentaba el nivel de WHWM. Las aves que consumieron la dieta control tuvieron mayores valores medios para peso eviscerado $(2,20$ $\mathrm{kg}$ ) y rendimiento canal $(77,86 \%)$. Los valores

Arch. Zootec. 61 (234): 229-234. 2012 
registrados para la grasa abdominal y órganos internos (hígado, pulmones, corazón y molleja) no mostraron ninguna tendencia particular. Del mismo modo se registraron pequeñas variaciones para los parámetros sanguíneos. El coste del alimento ingerido por ave disminuyó al aumentar los nivles de WHWM en las dietas.

Puede concluirse que el $10 \%$ de FM puede ser reemplazado con WHWM en las dietas de pollos sin efectos adversos sobre el crecimiento o la canal. El avance de transformar un desperdicio en un producto valioso puede permitir suministrar fuentes alternativas de proteína y calcio en las dietas de pollos y contribuir a resolver el problema del manejo de los residuos de incubación.

\section{INTRODUCTION}

In many African countries, feed cost accounts for up to $70 \%$ of poultry production. This is due to the high cost and scarcity of feed ingredients such as fish meal, methionine, lysine, etc. Consequently, efforts have been geared towards re-cycling non-conventional feed ingredients in the formulation of poultry diets with a view to maximizing profit. Recycling of crop residues, agro industrial byproducts and poultry by-products in animal nutrition has been documented in many studies. This approach is considered to be facilitating waste management.

Hatchery by-products from broiler hatcheries alone have been estimated to weigh approximately $23 \mathrm{~kg} / 1000$ eggs set at $55-60 \%$ moisture. Vandepopuliere (1976) estimated the annual hatchery waste produced in the U.S. from broiler and layer chick hatcheries to be 50900 and 18200 metric tons respectively. Abiola et al. (2003) reported that Harco breeders produced more hatching wastes than Anak broilers. Such wastes are usually incinerated, rendered or taken to landfills (Miller, 1984). The nutritional value of hatching wastes has been reported in earlier studies. Rasool et al. (1999) reported 44.25\% CP for hatchery waste meal of broilers. Abiola et al. (2003) reported $58 \%$ and $59.3 \%$ crude protein, $5.1 \%$ and $4.4 \%$ ash content for hatching wastes of Anak and Harco breeders respectively.

The use of hatchery by-products in broilers (Babiker et al., 1991), cockerels (Abiola, 2001) and layers (Abiola and Onunkwor, 2004) have been demonstrated in previous studies. Recycling large quantities of hatchery waste to agricultural lands raises some serious nutrient management and biosecurity issues (Deshmukh and Patterson, 1997). In addition, the high cost of disposal to the producer has necessitated the need for a technology that is cost effective to produce hatchery waste value added by-product. The objective of this study therefore was to determine the effect of partial replacement of fish meal with whole hatchery waste meal (WHWM) on growth traits, carcase characteristics, blood parameters and economic benefits of broilers.

\section{MATERIALS AND METHODS}

\section{COLLECTIONAND PROCESSING OFHATCHING WASTES}

Un-hatched incubator eggs (hatching waste) of Black Australorp breeder stock ( 8 months old and 3 months in lay) were collected from the Hatchery unit, Agricultural Research Council, Glen. The wastes were boiled in water at $100^{\circ} \mathrm{C}$ for 20 minutes and allowed to cool down for 2 to 3 hours. The boiled samples were broken into pieces and oven-dried at $70^{\circ} \mathrm{C}$ for one hour. The dried waste was milled to form whole hatchery waste meal (WHWM). Four broiler diets were prepared in which WHWM replaced FM (protein for protein) at 0, 10, 20 and $30 \%$ levels (table I).

\section{Management of biRdS}

A total of 180 day-old broiler chicks purchased from Country Birds Holding $(\mathrm{CBH})$ Ltd, Botshabelo Rd, Bloemfontein were used for the study. There were 4 treatments with 45 birds per treatment and 15 birds per replicate. Feed and water were provided ad libitum for 42 days. Necessary vaccinations and medications were carried out as at when due. 
Table I. Composition (\%) of experimental diets. (Composición (\%) de dietas experimentales).

\begin{tabular}{lcccc}
\hline & \multicolumn{4}{c}{ Replacement levels of WHWM } \\
Ingredients & $0 \%$ & $10 \%$ & $20 \%$ & $30 \%$ \\
\hline Maize & 53.00 & 53.00 & 53.00 & 53.00 \\
Soybean meal & 28.40 & 28.40 & 28.40 & 28.40 \\
Fish meal & 4.00 & 3.60 & 3.20 & 2.80 \\
WHWM & 0.00 & 0.70 & 1.40 & 2.10 \\
Wheat bran & 10.00 & 9.70 & 9.40 & 9.10 \\
Limestone & 1.20 & 1.20 & 1.20 & 1.20 \\
Mono-calcium & & & & \\
phosphate & 1.50 & 1.50 & 1.50 & 1.50 \\
Oyster shell & 1.00 & 1.00 & 1.00 & 1.00 \\
Premix & 0.25 & 0.25 & 0.25 & 0.25 \\
Salt & 0.25 & 0.25 & 0.25 & 0.25 \\
Methionine & 0.20 & 0.20 & 0.20 & 0.20 \\
Lysine & 0.20 & 0.20 & 0.20 & 0.20 \\
Total & 100.00 & 100.00 & 100.00 & 100.00 \\
& & & & \\
Nutrient composition & & & & \\
Moisture (\%) & 5.93 & 5.81 & 5.20 & 5.15 \\
Ash (\%) & 5.96 & 7.04 & 6.92 & 6.40 \\
Ether extract (\%) & 2.28 & 2.22 & 2.58 & 3.06 \\
Crude protein (\%) & 25.23 & 24.59 & 25.16 & 25.09 \\
Gross energy & 18.29 & 17.82 & 18.12 & 18.14 \\
Ca (g/100 g) & 1.35 & 1.46 & 1.68 & 1.53 \\
P (g/100 g) & 0.47 & 0.43 & 0.47 & 0.45 \\
Ca:P & $2.9: 1$ & $3.4: 1$ & $3.6: 1$ & $3.4: 1$ \\
\hline & & & & \\
\hline
\end{tabular}

\section{EXPERIMENTAL SITE}

The study was carried out on deep litter in the poultry unit, Agricultural Research Council, Glen.

\section{DATACOLLECTION}

Data were collected on growth (e.g. feed intake, weight gain, feed conversion, etc.) and carcass traits, blood parameters and economy of production. Growth response was determined on weekly basis. On the $42^{\text {nd }}$ day of the study, blood samples ( $2 \mathrm{~mL}$ each) were collected via the wing vein of 2 birds per replicate group into ethylene diamine tetra-acetate (EDTA) bottles for haematological parameters. Similarly, 2 birds per replicate were randomly selected for carcase traits. Dressed and organ weights were expressed as percentage of live weight.

\section{LABORATORY ANALYSIS}

Chemical analyses were determined in the department of Animal Science, University of Free State and UP Nutrilab, University of Pretoria. The 24 blood samples collected were examined at the NHLS Universitas Academic Laboratory, University of Free State for White blood cell (WBC), Red blood cell(RBC), Haemoglobin(HGB), Haematocrit (HCT), Mean corpuscular haemoglobin $(\mathrm{MCH})$ and Mean corpuscular haemoglobin concentration (MCHC).

\section{STATISTICAL ANALYSIS}

Data obtained were subjected to analysis of variance (ANOVA) in a complete randomized design (SAS, 1999) while means that were significantly $(\mathrm{p}<0.05)$ different were compared using Duncan's multiple range test (Duncan, 1955).

\section{RESULTS AND DISCUSSION}

Results of chemical analysis of the two test ingredients (table II) indicated that

Table II. Nutrient composition of FM and WHWM. (Composición de nutrientes de FM y WHWM).

\begin{tabular}{lcc}
\hline Nutrients & FM & WHWM \\
\hline Moisture (\%) & 8.17 & 4.85 \\
Ash (\%) & 12.73 & 18.12 \\
Ether extract (\%) & 10.70 & 23.94 \\
Crude protein (CP, \%) & 73.18 & 42.26 \\
Crude fibre (CF, \%) & 0.22 & 1.00 \\
Gross energy (GE) & 23.20 & 20.24 \\
Calcium (\%) & 3.14 & 10.97 \\
Phosphorus (\%) & 2.09 & 0.66 \\
Ca:P & $1.5: 1$ & $16.6: 1$ \\
ME (kcal kg) & 46.60 & 131.02 \\
\hline
\end{tabular}

FM: Fish meal; WHWM: Whole hatchery waste meal. *Values are means of two determinations; ** $\mathrm{ME}=$ 6.913 X GE-18.5 X CP-109.5 X CF (Larbier and Leclercq, 1992). 
ABIOLA, RADEBE, WESTHUIZEN AND UMESIOBI

Table III. Growth traits of broilers fed diets in which WHWM replaced FM. (Datos de crecimiento de pollos alimentados con dietas en las que WHWM reemplaza a FM).

\begin{tabular}{lccccr}
\hline & \multicolumn{5}{c}{ Diets } \\
Parameters & 1 & 2 & 3 & 4 & SEM \\
\hline Feed intake (g/bird/day) & 113.78 & 118.25 & 108.17 & 103.97 & 4.78 \\
Weight gain (g/bird/day) & $48.18^{\mathrm{a}}$ & $50.16^{\mathrm{a}}$ & $46.67^{\mathrm{a}}$ & $41.27^{\mathrm{ab}}$ & 2.10 \\
Feed conversion & 2.36 & 2.37 & 2.31 & 2.53 & 0.10 \\
Daily protein intake (g/bird/day) & 28.70 & 29.08 & 27.22 & 26.08 & 1.20
\end{tabular}

FM: Fish meal; WHWM: Whole hatchery waste meal.

a,b Means in the same row with different superscripts are significantly different $(p<0.05)$.

WHWM had higher contents of ash (18.12\%) and ether extract (23.94\%). The higher ash content could be due to the high content of eggshell at the time of processing. AFRIS (2007) indicated that approximately $84 \%$ of the eggshell is ash of which most is calcium carbonate. The higher ether extract content of WHWM could be associated with higher egg yolk content of infertile eggs in the processed samples. However, crude protein (CP) content of FM was $73.18 \%$ while that of WHWM was 42.26\%. Rasool et al. (1999) reported similar value of $44.25 \% \mathrm{CP}$ for hatchery waste meal of broilers. Presence of high eggshell in hatching waste reduces the CP content (Ristic and Kormanjos, 1988). Calcium-phosphorus ratio was $16.6: 1$ for WHWM as against 1.5:1 in the FM.

Results of growth traits are presented in table III. Feed intake and weight gain decreased as the levels of fish meal decreased in the diets. Broilers fed with diet 2 had highest values for feed intake (118.25 g/bird/day) and weight gain $(50.16 \mathrm{~g} / \mathrm{bird} /$ day $)$ while lowest values were recorded for broilers fed with diet 4. Results obtained indicated the superiority of fish meal over WHWM. In a similar study, Abiola and Onunkwor (2004)

Table IV. Carcass characteristics of broilers fed diets in which WHWM replaced FM. (Características de la canal de pollos de engorde alimentados con dietas en las que WHWM reemplaza a FM).

\begin{tabular}{lccccc}
\hline & \multicolumn{3}{c}{ Diets } & & \\
Parameters & 1 & 2 & 3 & 4 & SEM \\
\hline Liveweight (kg) & 2.83 & 2.76 & 2.54 & 2.54 & 0.17 \\
Eviscerated weight (kg) & $2.20^{\mathrm{a}}$ & $2.10^{\mathrm{a}}$ & $1.90^{\mathrm{a}}$ & $1.88^{\mathrm{ab}}$ & 0.13 \\
Dressing (\%) & 77.86 & 76.20 & 74.72 & 74.05 & 3.23 \\
Abdominal fat (\%) & 0.79 & 1.12 & 0.78 & 0.96 & 0.16 \\
Liver (\%) & 2.19 & 2.32 & 2.41 & 2.65 & 0.11 \\
Lungs (\%) & 0.67 & 0.70 & 0.80 & 0.61 & 0.04 \\
Heart (\%) & 0.54 & 0.49 & 0.54 & 0.55 & 0.03 \\
Gizzard (\%) & 1.68 & 1.31 & 1.24 & 1.52 & 0.13 \\
\hline
\end{tabular}

FM: Fish meal; WHWM: Whole hatchery waste meal.

${ }^{a, b}$ Means in the same row with different superscripts are significantly different $(p<0.05)$.

Archivos de zootecnia vol. 61, núm. 234, p. 232. 
Table $\boldsymbol{V}$. Blood parameters of broilers fed diets in which WHWM replaced FM. (Parámetros sanguíneos de pollos de engorde alimentados con dietas en las que WHWM reemplazan a FM).

\begin{tabular}{lccccr}
\hline & \multicolumn{3}{c}{ Diets } & & \\
Parameters & 1 & 2 & 3 & 4 & SEM \\
\hline WBC $\left(\times 10^{3} / \mathrm{L}\right)$ & $519.59^{\mathrm{a}}$ & $426.06^{\mathrm{b}}$ & $474.64^{\mathrm{b}}$ & $484.94^{\mathrm{ab}}$ & 37.35 \\
RBC $\left(10^{6} / \mathrm{mm}^{3}\right)$ & 2.49 & 2.41 & 2.35 & 2.67 & 0.14 \\
HGB $(\mathrm{g} / \mathrm{dL})$ & 8.70 & 8.17 & 8.23 & 8.77 & 0.48 \\
HCT $(\%)$ & 33.03 & 30.37 & 30.35 & 33.92 & 1.71 \\
MCH $(\mathrm{pg})$ & 34.93 & 34.02 & 34.95 & 32.97 & 1.16 \\
MCHC $(\mathrm{g} / \mathrm{dL})$ & 26.42 & 26.92 & 26.60 & 25.72 & 0.57 \\
\hline
\end{tabular}

FM: Fish meal; WHWM: Whole hatchery waste meal.

${ }^{a, b}$ Means in the same row with different superscripts are significantly different $(p<0.05)$.

reported decreased feed intake with decrease in levels of fish meal in layers diets. Body weight gain of cockerels decreased with increase in the levels of dried un-hatched incubators eggs in the diets (Abiola, 1999).

Results obtained for carcass traits (table IV) decreased with increase in the levels of WHWM in the diets. Broilers fed with control diet had highest mean values for eviscerated weight $(2.20 \mathrm{~kg})$ and dressing percentage $(77.86 \%)$. This could be indicative of poor utilization of nutrients in the WHWM diets. However, there were no significant effects on eviscerated weights when cockerels were fed hatchery waste meal diets (Abiola, 2001). Values recorded for abdominal fat and internal organs (liver, lungs, heart and gizzard) did not show any particular trend. Carcass quality depends on the level of calcium and phosphorus fed to animals (Driver et al., 2006). There were slight variations in the results obtained for blood parameters (table V) such as WBC, $\mathrm{RBC}, \mathrm{HGB}, \mathrm{HCT}, \mathrm{MCH}$ and $\mathrm{MCHC}$. WBC play prominent role in disease resistance especially with respect to the generation of antibodies. The lower values recorded for birds on WHWM diets is an indication that the birds were not reacting to the inclusion levels of WHWM. Values obtained particularly for packed cell volume (PCV), $\mathrm{Hb}$ and $\mathrm{RBC}$ were analogous with normal ranges reported for eight week-old broilers (Mitruka and Rawnsley, 1977). Table VI shows the feed cost analysis. Cost of total feed intake/ bird decreased with increase in the levels of WHWM in the diets. The lowest feed cost $/ \mathrm{kg}$ weight gain of R8.69 was recorded for broilers fed on diet three. Several studies have documented the use of hatching waste in poultry diet as means of reducing feed cost (Babiker et al., 1991; Abiola, 1999; Abiola, 2001; Abiola and Onunkwor, 2004).

Table VI. Feed cost analysis of broilers fed diets in which WHWM replaced FM. (Análisis de costes de alimentación de pollos consumiendo dietas en las que WHWM reemplaza FM).

\begin{tabular}{lcccc}
\hline & \multicolumn{4}{c}{ Diets } \\
Parameters & 1 & 2 & 3 & 4 \\
\hline $\begin{array}{l}\text { Cost of feed/kg (R) } \\
\begin{array}{l}\text { Cost of feed } \\
\text { intake/bird (R) }\end{array}\end{array}$ & 3.83 & 3.79 & 3.76 & 3.73 \\
$\begin{array}{l}\text { Feed cost/kg } \\
\text { wt. gain (R) }\end{array}$ & 18.37 & 24.84 & 17.08 & 16.28 \\
\hline
\end{tabular}

FM: Fish meal; WHWM: Whole hatchery waste meal.

$\mathrm{R}=\mathrm{Rand}(\mathrm{ZAR}) ; 1.00 \mathrm{US} \$=8.23 \mathrm{ZAR}$. 


\section{ABIOLA, RADEBE, WESTHUIZEN AND UMESIOBI}

\section{CONCLUSION}

Results of this study indicated that $10 \%$ of FM can be replaced with WHWM in broiler diets without adverse effects on growth and carcass traits. This approach will provide alternative protein and calcium sources in broiler diets and minimise problem of hatching waste disposal from hatchery industry.

\section{REFERENCES}

Abiola, S.S. 1999. Yield of un-hatched incubator eggs and it's replacement value in soybean meal diets fed to cockerels. Trop J Anim Sci, 1: 7478

Abiola, S.S. 2001. Substitution of groundnut-cake for hatchery waste meal in finisher diets of cockerels. Sci Forum, 4: 48-53.

Abiola, S.S., Balogun, O.A. and Adebiyi, R.A. 2003. Comparative evaluation of reproductive wastage in Anak broiler and Harco egg-type breeders. Bull Anim Health Prod in Africa, 51: 121-124.

Abiola, S.S. and Onunkwor, E.K. 2004. Replacement value of hatchery waste meal for fish mea in layer diets. Bioresource Tech, 95: 103-106.

AFRIS. 2007. Animal feed resources information system. http:www.fao.org/AG/agA/AGAP?FRG/ AFRIS/Data/329.htm (19/01/2008).

Babiker, S.A., El-Sammani, S.E. and Ismail, E.B. 1991. Incubator reject eggs as a protein supplement in the diets of broilers. Sudan $J$ Anim Prod, 4: 83-93.

Deshmukh, A.C. and Patterson, P.H. 1997 Preservation of hatchery waste by lactic acid fermentation. 2. Large-scale fermentation and feeding trial to evaluate feeding value. Poultry Sci, 76: 1220-1226.

\section{ACKNOWLEDGEMENT}

The Central University of Technology, Free State Research Grant Scheme is gratefully acknowledged for the award of grant towards the research project. The authors are also grateful to Agricultural Research Council, Glen for the provision of hatching waste and poultry house for project experimentation.

Driver, J.P., Pesti, G.M., Bakalli, R.I. and Edwards Jr., H.M. 2006. The effect of feeding diets to broiler chickens during the starting and growingfinishing phases on carcass quality. Poultry Sci, 85: 1939-1946.

Duncan, D.B. 1955. Multiple range and $F$ tests. Biometrics, 11: 1-42.

Larbier, M. and Leclercq, B. 1992. Nutrition and feeding of poultry. Nottingham University Press. Leicestershire, UK.

Miller, B.F. 1984. Extruding hatchery waste. Poultry Sci, 63: 1284-1286.

Mitruka, B.M. and Rawnsley, H. 1977. Clinical biochemical and haematological references value of normal experimental animals. Masbt Publisher. New York. pp. 171-174.

Rasool, S., Rehan, M., Haq, A. and Alam, M.Z. 1999. Preparation and nutritional evaluation of Hatchery waste meal for broilers. AsianAustralian J Anim Sci, 12: 554-557.

Ristic, M. and Kormanjos, S. 1988. Characteristics of egg incubation wastes and their processing to feed. Nutr Abst \& Review, 60 (1990): 2860.

SAS Institute. 1999. SAS User's Guide: Statistics. Inc. Cary, N.C. 923 pp.

Vandepopuliere, J.M. 1976. Convert hatchery waste into feedstuff. Poult Dig, 35: 247-248.

Archivos de zootecnia vol. 61, núm. 234, p. 234. 